\title{
BCL3 Gene
}

National Cancer Institute

\section{Source}

National Cancer Institute. BCL3 Gene. NCI Thesaurus. Code C18360.

This gene is involved in transcriptional co-activation and signal transduction. 